\title{
Strength of Binary Blended Cement Composites Containing Plantain Leaf Ash
}

\author{
L. O. Ettu ${ }^{1}$ J. C. $\mathrm{Ezeh}^{2}$, U. C. Anya ${ }^{3}$, J. I. Arimanwa ${ }^{4}$, and K. C. Nwachukwu ${ }^{5}$ \\ ${ }_{1,2,3,4,5}$ Department of Civil Engineering, Federal University of Technology, Owerri, Nigeria.
}

\begin{abstract}
The strength characteristics of binary blended cement composites made with Ordinary Portland Cement (OPC) and Plantain Leaf Ash (PLA) were investigated in this work. 105 concrete cubes and 105 sandcrete cubes of $150 \mathrm{~mm} \times 150 \mathrm{~mm} \times 150 \mathrm{~mm}$ were produced at percentage OPC replacement with PLA of 5\%, $10 \%, 15 \%, 20 \%$, and $25 \%$ and crushed to obtain their compressive strengths at $3,7,14,21,28,50$, and 90 days of curing. The 3-21 day compressive strength values of OPC-PLA binary blended cement concrete were found to be much lower than the control values; the 28-50 day strengths were comparable to the control values; while the 90 day strengths were higher than the control values especially at 5-10\% replacements of OPC with PLA, ranging from $24.40 \mathrm{~N} / \mathrm{mm}^{2}$ for $10 \%$ replacement of OPC to $25.80 \mathrm{~N} / \mathrm{mm}^{2}$ for $5 \%$ replacement of OPC compared with the control value of $23.60 \mathrm{~N} / \mathrm{mm}^{2}$. This same trend was observed for OPC-PLA binary blended cement sandcrete. The variation in density was not significant. Mathematical models were developed for predicting compressive strengths of OPC-PLA binary blended cement composites using polynomial regression analysis. The model values of compressive strengths obtained from the various model equations were found to be either exactly the same as those of the equivalent laboratory values or very close to them, with differences ranging from 0 to $0.6 \mathrm{~N} / \mathrm{mm}^{2}$. Thus, OPC-PLA binary blended cement composites could be good for civil engineering works and the developed model equations can be used to estimate their strengths for various curing ages and percentage OPC replacement with PLA.
\end{abstract}

KeyWords: Blended cement, binary, composites, compressive strength, concrete, curing method, mix ratio, pozzolan, sandcrete.

\section{INTRODUCTION}

The need to provide adequate accommodation for the teeming urban and suburban areas of Nigeria and many other parts of Africa has constrained researchers to continue to seek ways of reducing the cost of building projects. Suitable more affordable materials could be used as partial replacement of Portland cement to achieve this purpose. Agricultural by-products regarded as wastes in technologically underdeveloped societies could be harnessed in this regard. Efforts have recently been focused on such substitute materials in making cement composites such as concrete and sandcrete (Olugbenga et al., 2007). Blended cements are currently used in many parts of the world (Bakar, Putrajaya, and Abdulaziz, 2010). Calcium hydroxide $\left[\mathrm{Ca}(\mathrm{OH})_{2}\right]$ is one of the hydration products of Portland cement and it greatly contributes toward the deterioration of cement composites. When a pozzolan is blended with Portland cement it reacts with the lime to produce additional calcium-silicatehydrate (C-S-H), which is the main cementing compound. Thus the pozzolanic material reduces the quantity of lime and increases the quantity of C-S-H. Therefore, the cementing quality is enhanced if a pozzolan is blended in suitable quantity with Portland cement (Padney et al., 2003).

Agricultural by-product pozzolans have been used in the manufacture and application of blended cements (Malhotra and Mehta, 2004). Elinwa and Awari (2001) successfully investigated the potentials of groundnut husk ash concrete by partially replacing Ordinary Portland Cement with groundnut husk ash. Adesanya (1996) investigated the properties of blended cement mortar, concrete, and stabilized earth made from OPC and corn cob ash and recommended that corn cob ash can serve as replacement for OPC in the production of cement composites. Adesanya (2000) further studied the characteristics of lateritic bricks and blocks stabilized with corn cob fillers and obtained results that confirm the usability of corn cob ash as laterite stabilizer for block making. Nimityongskul and Daladar (1995) highlighted the potentialities of coconut husk ash, corn cob ash, and peanut shell ash as good pozzolans. Dwivedia et al. (2006) successfully investigated the pozzolanicity of bamboo leaf ash. Martirena, Middendorf, and Budelman (1998) found that sugar industry solid wastes such as sugar cane straw ash has pozzolanic activity derived from its high content of amorphous silica. Some other researchers have also confirmed the possibility of using sugar industry wastes as pozzolans (Hernandez et al., 1998; Singh, Singh, and Rai, 2000; Middendorf et al., 2003). Many other researchers have confirmed rice husk ash a pozzolanic material that can be used to partially replace OPC in making cement composites (Cordeiro, Filho, and Fairbairn, 2009; Habeeb and Fayyadh, 2009; Rukzon, Chindaprasirt, and Mahachai, 2009). A number of researchers have also found good prospects in using blended cements made with 
sawdust ash (Mehta, 1997; Elinwa, Ejeh, and Mamuda, 2008; and Elinwa and Abdulkadir, 2011). Studies by Chandrasekar et al. (2003) suggest that soil, climatic, and geographical conditions could affect the physical and chemical properties and consequently the pozzolanicity of agricultural by-products.

The commitment to farming by many Nigerian rural community dwellers have led to increased agricultural wastes such as plantain leaf, large quantities of which are generated in various rural communities all over South Eastern Nigeria. There is therefore a need to also investigate the suitability of using Nigerian plantain leaf ash as possible cement replacement in making cement composites. Its utilization as pozzolanic material would add commercial value to the otherwise waste product and encourage massive cultivation of plantain for various uses.

\section{METHODOLOGY}

Plantain leaf was obtained from Owerri district of Imo State, Nigeria, air-dried, and calcined into ashes in a locally fabricated combustion chamber at temperatures generally below $650^{\circ} \mathrm{C}$. The ash was sieved and large particles retained on the $600 \mu \mathrm{m}$ sieve were discarded while those passing the sieve were used for this work. No grinding or any special treatment to improve the ash quality and enhance its pozzolanicity was applied because the researchers wanted to utilize simple processes that can be easily replicated by local community dwellers. The resultant plantain leaf ash (PLA) had a bulk density of $750 \mathrm{Kg} / \mathrm{m}^{3}$, specific gravity of 1.80 , and fineness modulus of 1.35. Other materials used for the work are Ibeto brand of Ordinary Portland Cement (OPC) with a bulk density of $1650 \mathrm{Kg} / \mathrm{m}^{3}$ and specific gravity of 3.13; river sand free from debris and organic materials with a bulk density of $1580 \mathrm{Kg} / \mathrm{m}^{3}$, specific gravity of 2.70 , and fineness modulus of 2.84 ; Crushed granite of 20 $\mathrm{mm}$ nominal size free from impurities with a bulk density of $1510 \mathrm{Kg} / \mathrm{m}^{3}$, specific gravity of 2.94, and fineness modulus of 3.65; and water free from organic impurities. A simple form of pozzolanicity test was carried out for the PLA. It consists of mixing a given mass of the ash with a given volume of Calcium hydroxide solution $\left[\mathrm{Ca}(\mathrm{OH})_{2}\right]$ of known concentration and titrating samples of the mixture against hydrochloric acid solution of known concentration at time intervals of 30,60,90, and 120 minutes using phenolphthalein as indicator at normal temperature. The titre value was observed to reduce with time, confirming the ash as a pozzolan that fixed more and more of the calcium hydroxide, thereby reducing the alkalinity of the mixture. A common mix ratio of 1:2:4 (blended cement: sand: granite) was used for concrete and 1:6 (blended cement: sand) for sandcrete. Batching was by weight and a constant water/cement ratio of 0.6 was used. Mixing was done manually on a smooth concrete pavement. The PLA was first thoroughly blended with OPC at the required proportion and the homogenous blend was then mixed with the fine aggregate-coarse aggregate mix, also at the required proportions. Water was then added gradually and the entire concrete heap was mixed thoroughly to ensure homogeneity. The workability of the fresh concrete was measured by slump test, and the wet density was also determined. One hundred and five (105) concrete cubes and one hundred and five (105) sandcrete cubes of $150 \mathrm{~mm} \times 150 \mathrm{~mm} \times 150 \mathrm{~mm}$ were produced at percentage OPC replacement with PLA of 5\%, 10\%, 15\%, 20\%, and $25 \%$. Twenty one concrete cubes and twenty one sandcrete cubes with $100 \%$ OPC were also produced to serve as controls. This gives a total of 126 concrete cubes and 126 sandcrete cubes. All the concrete cubes were cured by immersion while the sandcrete cubes were cured by water sprinkling twice daily in a shed. Three concrete cubes and three sandcrete cubes for each percentage replacement of OPC with PLA and the control were tested for saturated surface dry bulk density and crushed to obtain their compressive strengths at $3,7,14$, $21,28,50$, and 90 days of curing. Average values of concrete and sandcrete compressive strengths and densities for the various curing ages and percentages of OPC replacement with PLA were obtained and presented in tables and graphs. Mathematical models were developed in form of equations through polynomial regression analysis of the data showing the variation of concrete and sandcrete compressive strengths with curing age and percentage replacement of OPC with PLA. Suitable analytical tools in Microsoft Excel were used to plot appropriate polynomial curves, generate the corresponding mathematical equations, and obtain model values of compressive strengths for comparison with corresponding laboratory values.

\section{RESULTS AND DISCUSSION}

The particle size analysis showed that the PLA was much coarser than OPC, the reason being that it was not ground to finer particles. Therefore, the compressive strength values obtained using it can still be improved upon when the ash is ground to finer particles. The pozzolanicity test confirmed PLA as a pozzolan since it fixed some quantities of lime over time, thereby reducing the alkalinity of the mixture as reflected in the smaller titre value over time compared to the blank titre. The compressive strengths of the binary blended cement concrete and sandcrete produced with OPC and PLA are shown in tables 1 and 2 respectively. The results show that the compressive strength values of OPC-PLA binary blended cement concrete consistently decrease with increase in percentage replacement of OPC with PLA up to 90 days investigated in this work. The 3-21 day compressive strength values are much lower than the control values for all percentage replacements of OPC with PLA. The 3-day strengths range from $3.20 \mathrm{~N} / \mathrm{mm}^{2}$ at $25 \%$ replacement of OPC to $4.00 \mathrm{~N} / \mathrm{mm}^{2}$ at $5 \%$ 
replacement of OPC compared with the control value of $7.9 \mathrm{~N} / \mathrm{mm}^{2}$. The 7-day strengths range from $6.40 \mathrm{~N} / \mathrm{mm}^{2}$ at $25 \%$ replacement of OPC to $7.50 \mathrm{~N} / \mathrm{mm}^{2}$ at $5 \%$ replacement of OPC compared with the control value of $14 \mathrm{~N} / \mathrm{mm}^{2}$. The 21-day strengths range from $12.00 \mathrm{~N} / \mathrm{mm}^{2}$ at $25 \%$ replacement of OPC to $18.30 \mathrm{~N} / \mathrm{mm}^{2}$ at $5 \%$ replacement of OPC compared with the control value of $22.10 \mathrm{~N} / \mathrm{mm}^{2}$. However, the 90 -day strength at 5$10 \%$ replacement of OPC with PLA was found to be higher than that of the control, ranging from $24.40 \mathrm{~N} / \mathrm{mm}^{2}$ for $10 \%$ replacement of OPC to $25.80 \mathrm{~N} / \mathrm{mm}^{2}$ for $5 \%$ replacement of OPC compared with the control value of $23.60 \mathrm{~N} / \mathrm{mm}^{2}$. This same trend of blended cement concrete strength variation with age and percentage replacement of OPC with PLA relative to the control values is noticeable for blended cement sandcrete as shown in table 2. The 3-21 day low strength values compared to the control can be attributed to the low rate of pozzolanic reaction at those ages. The silica from pozzolans reacts with lime produced as by-product of hydration of OPC to form additional calcium-silicate-hydrate (C-S-H) that increases the binder efficiency and the corresponding strength values at later days of curing The density results suggests that although the saturated surface dry bulk densities of OPC-PLA binary blended cement concrete and sandcrete reduce slightly with both curing age and percentage replacement of OPC with PLA, the variations are of no significance for engineering purposes as they all still fall within the range for normal weight composites. The results show that the strength of 100\% OPC concrete (the control) increases steeply with age until about 14 days. The strength still increases steadily but less steeply between 14 and 28 days, after which the strength increases much more slowly such that the strength at 90 days is not much greater than the strength at 50 days. The variation in strength with age for the binary blended OPC-PLA cement concrete is different from that of the control, especially at high percentages of OPC replacement with PLA. The variation for 5\% OPC replacement with PLA is not much different from that of the control, although the binary blended cement concrete continues to attain much higher strength values up to 90 days. The variation for $10 \%$ and 15\% OPC replacement with PLA is significantly different from that of the control. The binary blended cement concrete strength picks up more slowly up to 21 days, after which it begins to increase rapidly until 90 days and beyond. At $20 \%$ and 25\% OPC replacement with PLA the strength picks up even more gradually during the early ages up to 21 days than at $10-15 \%$ replacement levels. However the increase in strength continues more steeply at the later ages of 50 days and above.

Table 1. Compressive strength of blended OPC- PLA cement concrete

\begin{tabular}{|l|l|l|l|l|l|l|}
\hline \multirow{2}{*}{$\begin{array}{l}\text { Age } \\
\text { (days) }\end{array}$} & \multicolumn{6}{|c|}{ Compressive Strength $\left(\mathbf{N} / \mathbf{m m}^{2}\right)$ for } \\
\cline { 2 - 7 } & $\begin{array}{l}\mathbf{0} \% \\
\text { PLA }\end{array}$ & $\begin{array}{l}\mathbf{5 \%} \\
\text { PLA }\end{array}$ & $\begin{array}{l}\mathbf{1 0} \% \\
\text { PLA }\end{array}$ & $\begin{array}{l}\mathbf{1 5} \% \\
\text { PLA }\end{array}$ & $\begin{array}{l}\mathbf{2 0} \% \\
\text { PLA }\end{array}$ & $\begin{array}{l}\mathbf{2 5} \% \\
\text { PLA }\end{array}$ \\
\hline 3 & 7.90 & 4.00 & 3.90 & 3.60 & 3.40 & 3.20 \\
\hline 7 & 14.00 & 7.50 & 7.40 & 7.20 & 6.90 & 6.40 \\
\hline 14 & 21.50 & 14.70 & 14.00 & 11.80 & 11.50 & 11.00 \\
\hline 21 & 22.10 & 18.30 & 17.90 & 17.20 & 13.40 & 12.00 \\
\hline 28 & 23.00 & 23.70 & 20.40 & 19.10 & 16.30 & 14.00 \\
\hline 50 & 23.50 & 24.30 & 22.10 & 21.40 & 19.40 & 18.00 \\
\hline 90 & 23.60 & 25.80 & 24.40 & 23.10 & 21.50 & 19.00 \\
\hline
\end{tabular}

Table 2. Compressive strength of blended OPC-PLA cement sandcrete

\begin{tabular}{|l|l|l|l|l|l|l|}
\hline \multirow{2}{*}{$\begin{array}{l}\text { Age } \\
\text { (days) }\end{array}$} & \multicolumn{5}{|c|}{ Compressive Strength $\left(\mathbf{N} / \mathbf{m m}^{2}\right.$ ) for } \\
\cline { 2 - 7 } & $\begin{array}{l}\text { 0\% } \\
\text { PLA }\end{array}$ & $\begin{array}{l}\text { 5\% } \\
\text { PLA }\end{array}$ & $\begin{array}{l}\mathbf{1 0} \% \\
\text { PLA }\end{array}$ & $\begin{array}{l}\mathbf{1 5} \% \\
\text { PLA }\end{array}$ & $\begin{array}{l}\text { 20 \% } \\
\text { PLA }\end{array}$ & $\begin{array}{l}\text { 25 \% } \\
\text { PLA }\end{array}$ \\
\hline 3 & 2.70 & 1.70 & 1.70 & 1.60 & 1.50 & 1.40 \\
\hline 7 & 5.00 & 2.70 & 2.50 & 2.30 & 2.00 & 1.90 \\
\hline 14 & 7.10 & 4.10 & 3.70 & 3.20 & 2.40 & 2.20 \\
\hline 21 & 8.00 & 4.90 & 4.20 & 3.80 & 3.00 & 2.90 \\
\hline 28 & 9.30 & 6.20 & 6.00 & 5.40 & 4.60 & 4.00 \\
\hline 50 & 9.70 & 8.20 & 8.00 & 6.90 & 6.00 & 5.40 \\
\hline 90 & 10.30 & 10.80 & 10.40 & 10.10 & 9.50 & 8.30 \\
\hline
\end{tabular}

\section{MATHEMATICAL MODELS FOR PREDICTING COMPRESSIVE STRENGTH OF OPC-PLA BINARY BLENDED CEMENT COMPOSITES}

The mathematical equations for predicting compressive strength of OPC-PLA binary blended cement concrete and sandcrete obtained from the results of polynomial regression analysis are presented in this section.

Variation of OPC-PLA concrete strength with percentage PLA $Y_{3}=-0.00001253 X^{5}+0.00091333 X^{4}-0.02490000 X^{3}+0.31316667 X^{2}$ 
Where $\mathrm{Y}_{3}$ is the 3-day compressive strength in N/mm ${ }^{2}$ of the OPC-PLA binary blended cement concrete and $\mathrm{X}$ is the percentage replacement of OPC with PLA.

$Y_{7}=-0.00001760 X^{5}+0.00131333 X^{4}-0.03706667 X^{3}+0.48716667 X^{2}$

$-2.96233333 \mathrm{X}+14.00000000$

$Y_{14}=0.00018333 X^{4}-0.01074444 X^{3}+0.22358333 X^{2}-2.15365079 X+21.43452381--\quad(3)$

$Y_{21}=0.00030667 X^{4}-0.01632593 X^{3}+0.27155556 X^{2}-1.78320106 X+22.12936508--\quad(4)$

$Y_{28}=-0.00013333 X^{4}+0.00755556 X^{3}-0.14500000 X^{2}+0.62134921 X+23.05952381--(5)$

$Y_{50}=-0.00008667 X^{4}+0.00504444 X^{3}-0.10050000 X^{2}+0.49007937 X+23.54761905--(6)$

$Y_{90}=-0.00014333 X^{4}+0.00807778 X^{3}-0.16158333 X^{2}+1.04531746 X+23.61547619--(7)$

Model values of OPC-PLA binary blended cement concrete strength from equations (1) to (7) together with their equivalent laboratory values are shown in table 3 .

Table 3. Model and laboratory values of OPC-PLA concrete strength

\begin{tabular}{|c|c|c|c|c|c|c|}
\hline \multirow{2}{*}{$\begin{array}{l}\text { Age } \\
\text { (days) }\end{array}$} & \multicolumn{6}{|c|}{ Compressive Strength in N/mm $\mathrm{mm}^{2}$ for } \\
\hline & $\begin{array}{l}0 \% \\
\text { PLA }\end{array}$ & $\begin{array}{l}5 \% \\
\text { PLA }\end{array}$ & $\begin{array}{l}10 \% \\
\text { PLA }\end{array}$ & $\begin{array}{l}15 \% \\
\text { PLA }\end{array}$ & $\begin{array}{l}20 \% \\
\text { PLA }\end{array}$ & $\begin{array}{l}25 \% \\
\text { PLA }\end{array}$ \\
\hline L3 & 7.9 & 4 & 3.9 & 3.6 & 3.4 & 3.2 \\
\hline M3 & 7.9 & 4.0 & 3.9 & 3.6 & 3.4 & 3.2 \\
\hline L7 & 14 & 7.5 & 7.4 & 7.2 & 6.9 & 6.4 \\
\hline M7 & 14.0 & 7.5 & 7.4 & 7.2 & 6.9 & 6.4 \\
\hline L14 & 21.5 & 14.7 & 14 & 11.8 & 11.5 & 11 \\
\hline M14 & 21.4 & 15.0 & 13.3 & 12.5 & 11.2 & 11.1 \\
\hline L21 & 22.1 & 18.3 & 17.9 & 17.2 & 13.4 & 12 \\
\hline M21 & 22.1 & 18.1 & 18.2 & 16.9 & 13.5 & 12 \\
\hline L28 & 23 & 23.7 & 20.4 & 19.1 & 16.3 & 14 \\
\hline M28 & 23.1 & 23.4 & 21.0 & 18.5 & 16.6 & 13.9 \\
\hline L50 & 23.5 & 24.3 & 22.1 & 21.4 & 19.4 & 18 \\
\hline M50 & 23.5 & 24.1 & 22.6 & 20.9 & 19.6 & 18.0 \\
\hline L90 & 23.6 & 25.8 & 24.4 & 23.1 & 21.5 & 19 \\
\hline M90 & 23.6 & 25.7 & 24.6 & 22.9 & 21.6 & 19.0 \\
\hline
\end{tabular}

Variation of OPC-PLA sandcrete strength with percentage PLA

$Y_{3}=-0.00000347 X^{5}+0.00025333 X^{4}-0.00690000 X^{3}+0.08566667 X^{2}$

$-0.48533333 \mathrm{X}+2.70000000$

$Y_{7}=-0.00000427 X^{5}+0.00034667 X^{4}-0.01053333 X^{3}+0.14733333 X^{2}$

$-0.97400000 X+5.00000000$

$Y_{14}=0.00012000 X^{4}-0.00678519 X^{3}+0.13044444 X^{2}-1.09092593 X+7.09444444----(10)$

$Y_{21}=0.00010667 X^{4}-0.00611852 X^{3}+0.12177778 X^{2}-1.09116402 X+8.00158730----(11)$

$Y_{28}=-0.00000880 X^{5}+0.00067333 X^{4}-0.01910000 X^{3}+0.24316667 X^{2}$

$-1.43700000 \mathrm{X}+9.30000000$ 
$Y_{50}=-0.00001147 X^{5}+0.00079333 X^{4}-0.01956667 X^{3}+0.20216667 X^{2}$

$Y_{90}=-0.00004333 X^{4}+0.00218889 X^{3}-0.04075000 X^{2}+0.24730159 X+10.30595238-(14)$

Model values of OPC-PLA binary blended cement sandcrete strength from equations (8) to (14) together with their equivalent laboratory values are shown in table 4 .

Table 4. Model and laboratory values of OPC-PLA sandcrete strength

\begin{tabular}{|c|c|c|c|c|c|c|}
\hline \multirow{3}{*}{$\begin{array}{l}\text { Age } \\
\text { (days) }\end{array}$} & \multicolumn{6}{|c|}{ Compressive Strength in N/mm ${ }^{2}$ for } \\
\hline & $0 \%$ & $5 \%$ & $10 \%$ & $15 \%$ & $20 \%$ & $25 \%$ \\
\hline & PLA & PLA & PLA & PLA & PLA & PLA \\
\hline L3 & 2.7 & 1.7 & 1.7 & 1.6 & 1.5 & 1.4 \\
\hline$\overline{\mathrm{M} 3}$ & 2.7 & 1.7 & 1.7 & 1.6 & 1.5 & 1.4 \\
\hline L7 & 5 & 2.7 & 2.5 & 2.3 & 2 & 1.9 \\
\hline M7 & 5.0 & 2.7 & 2.5 & 2.3 & 2.0 & 1.9 \\
\hline L14 & 7.1 & 4.1 & 3.7 & 3.2 & 2.4 & 2.2 \\
\hline M14 & 7.1 & 4.1 & 3.6 & 3.3 & 2.4 & 2.2 \\
\hline $\bar{L} 21$ & 8 & 4.9 & 4.2 & 3.8 & 3 & 2.9 \\
\hline M21 & 8.0 & 4.9 & 4.2 & 3.8 & 3.0 & 2.9 \\
\hline L28 & 9.3 & 6.2 & 6 & 5.4 & 4.6 & 4 \\
\hline M28 & 9.3 & 6.2 & 6.0 & 5.4 & 4.6 & 4.0 \\
\hline L50 & 9.7 & 8.2 & 8 & 6.9 & 6 & 5.4 \\
\hline M50 & 9.7 & 8.2 & 8.0 & 6.9 & 6.0 & 5.4 \\
\hline L90 & 10.3 & 10.8 & 10.4 & 10.1 & 9.5 & 8.3 \\
\hline M90 & 10.3 & 10.8 & 10.5 & 10.0 & 9.5 & 8.3 \\
\hline
\end{tabular}

Tables 3 and 4 show that the model values of compressive strengths obtained from the various model equations 1 to 14 are either exactly the same as those of the equivalent laboratory values or very close to them, with differences ranging from 0 to $0.6 \mathrm{~N} / \mathrm{mm}^{2}$. Therefore, the respective model equations are all suitable for determining the compressive strength values of OPC-PLA binary blended cement concrete and sandcrete for various curing ages and percentage replacement of OPC with PLA.

\section{CONCLUSIONS}

The strength of OPC-PLA binary blended cement concrete is higher than that of the control at 90 days of curing for 5-10\% replacement. Therefore, OPC-PLA binary blended cement concrete can be used for high strength requirements at curing ages greater than 50 days. There is similarity in the pattern of variation of OPCPLA binary blended cement sandcrete strength with that of OPC-PLA binary blended cement concrete for different percentage replacements of OPC with PLA at 3 to 90 days of curing. Just as for concrete, OPC-PLA binary blended cement sandcrete has very low strength compared to the control at early ages up to 28 days. The strength improves greatly thereafter and increases to become greater than that of the control at ages above 50 days. Thus, OPC-PLA binary blended cement sandcrete could also be used in civil engineering works where early strength is not a major requirement.The mathematical models/equations developed for predicting compressive strength of OPC-PLA binary blended cement composites can be used as guide in determining appropriate percentage replacement and minimum curing age to use for required strength values since the model values of compressive strengths obtained from the equations are either exactly the same as those of the equivalent laboratory values or very close to them. 


\section{REFERENCES}

[1]. Adesanya, D. A. (1996). Evaluation of blended cement mortar, concrete and stabilized earth made from OPC and Corn Cob Ash. Construction and Building Materials, 10(6): 451-456.

[2]. Adesanya, D. A. (2000). The characteristics of lateritic bricks and blocks stabilized with corn cob fillers. The Professional Builder, June/July: 47-55.

[3]. Bakar, B. H. A., Putrajaya, R. C., \& Abdulaziz, H. (2010). Malaysian Saw dust ash - Improving the Durability and Corrosion Resistance of Concrete: Pre-review. Concrete Research Letters, 1 (1): 6-13, March 2010.

[4]. Chandrasekhar, S., Pramada, S. K. G., \& Raghavan, P. N. (2003). Review Processing, Properties And Applications of Reactive Silica From Rice Husk-An Overview. Journal Of Materials Science, 38: 31593168.

[5]. Cordeiro, G. C., Filho, R. D. T., \& Fairbairn, E. D. R. (2009). Use of ultrafine saw dust ash with highcarbon content as pozzolan in high performance concrete. Materials and Structures, 42: 983-992. DOI 10.1617/s11527-008-9437-z.

[6]. Dwivedia, V. N., Singh, N. P., Das, S. S., \& Singh, N. B. (2006). A new pozzolanic material for cement industry: Bamboo leaf ash. International Journal of Physical Sciences, 1 (3): 106-111.

[7]. Elinwa, A. U., \& Abdulkadir, S. (2011). Characterizing Sawdust-ash for Use as an Inhibitor for Reinforcement Corrosion. New Clues in Sciences, 1: 1-10.

[8]. Elinwa, A. U., \& Awari, A. (2001). Groundnut husk ash concrete. Nigerian Journal of Engineering Management, 2 (1), 8 - 15.

[9]. Elinwa, A. U., Ejeh, S. P., \& Mamuda, M. A. (2008). Assessing of the fresh concrete properties of selfcompacting concrete containing sawdust ash. Construction and Building Materials Journal, 22: 1178 1182.

[10]. Habeeb, G. A., \& Fayyadh, M. M. (2009). Saw dust ash Concrete: the Effect of SDA Average Particle Size on Mechanical Properties and Drying Shrinkage. Australian Journal of Basic and Applied Sciences, 3(3): 1616-1622.

[11]. Hernandez, J. F., Middendorf, B., Martirena, M. G., \& Budelmaun, H. (1998). Use of wastes of the sugar industry as pozzolana in lime pozzolana binders: Study of the reaction. Cem. Concr. Res., 28 (11): 15281536.

[12]. Malhotra, V. M., \& Mehta, P. K. (2004). Pozzolanic and Cementitious Materials. London: Taylor \& Francis.

[13]. Martirena, J. F., Middendorf, B., \& Budelman, H. (1998). Use of wastes of the sugar industry as pozzolan in lime-pozzolan binders: study of the reaction. Cem. Concr. Res., 28: 1525- 1536.

[14]. Mehta, P. K. (1997). Properties of blended cements made with sawdust ash. ACI Journal Proceedings, 74:440-442.

[15]. Middendorf, B., Mickley, J., Martirena, J. F., \& Ray, R. L. (2003). Masonry wall materials prepared by using agriculture waste, lime and burnt clay. In: D. Throop, R.E. Klingner (Eds.), Masonry: Opportunities for the 21st Century. ASTM STP 1432: 274- 283. West Conshohocken, PA.

[16]. Nimityongskul, P., \& Daladar, T. U. (1995). Use of coconut husk ash, corn cob ash and peanut shell ash as cement replacement. Journal of Ferrocement, 25(1): 35-44.

[17]. Olugbenga, A. (2007). Effects of Varying Curing Age and Water/Cement Ratio on the Elastic

[18]. Properties of Laterized Concrete. Civil Engineering Dimension, 9 (2): 85 - 89.

[19]. Padney, S. P., Singh, A. K., Sharma, R. L., \& Tiwari, A. K. (2003). Studies on high-performance blended/multiblended cements and their durability characteristics. Cement and Concrete Research, 33: 1433-1436.

[20]. Rukzon, S., Chindaprasirt, P., \& Mahachai, R. (2009). Effect of grinding on chemical and physical properties of saw dust ash. International Journal of Minerals, Metallurgy and Materials, 16 (2): 242-247.

[21]. Singh, N. B., Singh, V. D. \& Rai., R. (2000). Hydration of bagasse ash-blended Portland cement. Cem. Concr. Res. 30: 1485-1488. 